\title{
Aplikasi Matrix Labolatory untuk Perhitungan Sistem Antrian dengan Server Tunggal dan Majemuk
}

\author{
Nafiul Anam ${ }^{1}$ \& Putriaji Hendikawati ${ }^{2}$ \\ ${ }^{1}$ Program Studi Statistika Terapan dan Komputasi FMIPA Unnes \\ ${ }^{2}$ Jurusan Matematika FMIPA Unnes \\ Email: p_aji_unnes@yahoo.com
}

\begin{abstract}
Abstrak. Penelitian ini mengembangkan program aplikasi komputer dengan Matrix Labolatory (Matlab) sebagai alat bantu untuk menghitung aplikasi teori antrian. Program aplikasi yang dirancang dapat digunakan untuk menghitung berbagai komponen antrian seperti laju kedatangan dan pelayanan serta distribusinya, probabilitas pelayan menganggur, jumlah pelanggan serta waktu tunggu dalam antrian. Berdasarkan analisis dan perancangan program, perhitungan antrian yang dilakukan memiliki ketepatan hasil yang sama terhadap perhitungan secara teoretis dan mampu meningkatkan efisiensi waktu dalam perhitungan aplikasi sistem antrian. Program yang dibuat pada penelitian ini hanya terbatas untuk menghitung model antrian server tunggal dan majemuk dengan laju kedatangan berdistribusi poisson dan laju pelayanan berdistribusi eksponensial, untuk itu perlu pengembangan program lebih lanjut untuk model antrian dengan laju kedatangan dan pelayanan yang tidak memenuhi asumsi distribusi poisson dan eksponensial.
\end{abstract}

Kata kunci:Matrix Labolatory; distribusi poison.

\section{PENDAHULUAN}

Antrian terjadi pada kondisi dimana objek-objek menuju suatu fasilitas pelayanan namun kemudian menghadapi keterlambatan karena mekanisme pelayanan mengalami kesibukan. Hal ini disebabkan antara lain karena kebutuhan akan layanan melebihi kapasitas pelayanan. Teori antrian adalah teori yang menyangkut studi matematis dari antrian-antrian atau baris-baris penungguan [1]. Proses antrian merupakan proses yang berhubungan dengan kedatangan pelanggan pada suatu fasilitas pelayanan, menunggu panggilan dalam baris antrian jika belum mendapat pelayanan dan akhirnya meninggalkan fasilitas pelayanan setelah mendapat pelayanan [2].

Pada teori antrian harus diketahui sistem antrian serta keadaan sistem yang digunakan, adapun sistem antrian merupakan himpunan pelanggan, pelayan dan suatu aturan yang mengatur pelayanan pada pelanggan.Sedangkan keadaan sistem menunjuk pada jumlah pelanggan yang berada dalam suatu fasilitas 
pelayanan, termasuk dalam antriannya sehingga dapat diketahui model antrian yang sesuai.Pemanfaatan teori antrian dapat diterapkan untuk mengoptimalkan pelayanan dengan merencanakan sumber daya penyelenggara layanan sehingga pelayanan menjadi efektif dan efisien dimana waktu tunggu pelanggan tidak terlalu lama dan pelayan tidak banyak waktu menganggur sehingga dapat meminimalkan biaya layanan. Untuk menghitung suatu model antrian, harus diketahui komponen-komponen yang digunakan untuk perhitungan seperti ratarata waktu kedatangan pelanggan $(\lambda)$, rata-rata waktu pelayanan $(\mu)$, kapasitas pelayanan, bentuk dan disiplin antrian.

Pada teori antrian ada empat jenis disiplin antrian yaitu First In First Out (FIFO), Last In First Out (LIFO), Service In Random Order (SIRO)dan Pelayanan Berdasarkan Prioritas (PRI) [2]. Sedangkan menurut [3] ada empat macam bentuk antrian, yaitu:

1. Single Channel-Single Phase

Single Channel berarti hanya ada satu jalur yang memasuki sistem pelayanan atau ada satu fasilitas pelayanan. Single Phase berarti hanya ada satu pelayanan.Lebih jelasnya lihat Gambar 1 .

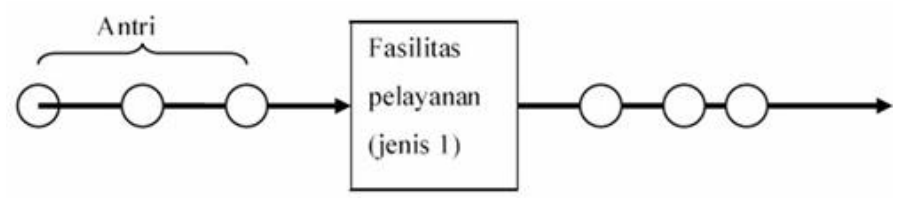

Gambar 1Single Channel-Single Phase.

\section{Single Channel-Multi Phase}

Istilah Multi Phase menunjukkan ada dua atau lebih pelayanan yang dilaksanakan secara berurutan (dalam phase-phase).Seperti terlihat pada Gambar 2.

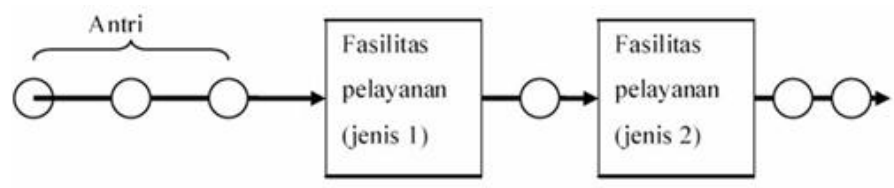

Gambar 2Single Channel-Multi Phase.

3. Multi Channel-Single Phase 
Sistem Multi Channel-Single Phase terjadi di mana terdapat dua atau lebih fasilitas pelayanan yang dialiri oleh antrian tunggal, seperti terlihat pada Gambar 3.

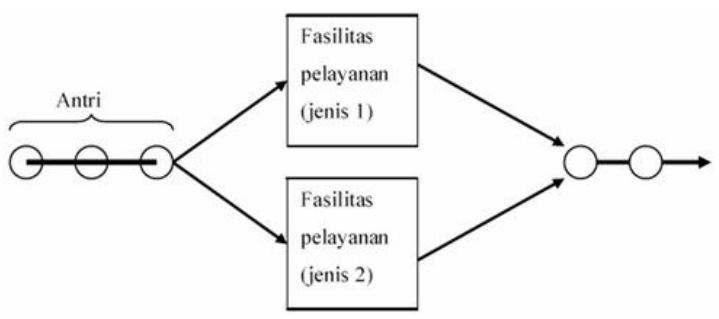

Gambar 3Multi Channel-Single Phase.

\section{Multi Channel-Multi Phase}

Sistem Multi Channel-Multi Phase memiliki beberapa fasilitas pelayanan pada setiap tahapnya. Seperti terlihat pada Gambar 4.

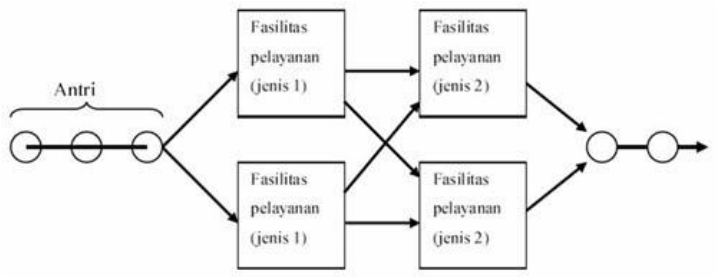

Gambar 4Multi Channel- Multi Phase.

Untuk menentukan model antrian yang sesuai, terlebih dahulu harus diketahui distribusi waktu kedatangan dan pelayanan pelanggan.Fokus pada tulisan ini adalah model antrian dengan laju kedatangan yang berdistribusi poisson dan laju pelayanan dengan distribusi eksponensial dengan jumlah server tunggal dan majemuk. Keempat model antrian tersebut yaitu:

1. Populasi Tidak Terbatas dengan Pelayanan (Server) Tunggal (M/M/1): $(\mathrm{GD} / \infty / \infty)$

$$
\begin{aligned}
& \rho=\frac{\lambda}{\mu} \\
& P_{0}=1-\rho \\
& P_{n}=\left(1-\frac{\lambda}{\mu}\right)\left(\frac{\lambda}{\mu}\right)^{n}
\end{aligned}
$$




$$
\begin{aligned}
L_{s} & =\frac{\lambda}{\mu-\lambda} \\
L_{q} & =\frac{\lambda^{2}}{\mu(\mu-\lambda)} \\
W_{s} & =\frac{L_{s}}{\lambda} \\
W_{q} & =W_{s}-\frac{1}{\mu}
\end{aligned}
$$

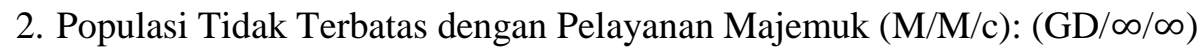

$$
\begin{aligned}
& \mu_{n}\left\{\begin{array}{l}
n \mu, n \leq c \\
c \mu, n \geq c
\end{array} \text { dan } \lambda_{n}=\lambda, \quad n \geq c\right. \\
& P_{n}= \begin{cases}\frac{\rho^{n}}{n !} P_{0}, & 0 \leq n \leq c \\
\frac{\rho^{n}}{c^{n-c} c !} P_{0}, & n>c\end{cases} \\
& P_{0}=\left[\frac{\rho^{c}}{c !\left(1-\frac{\rho}{c}\right)}+\sum_{n=0}^{c-1} \frac{\rho^{2}}{n !}\right]^{-1} \\
& L_{q}=\left[\frac{c \rho}{(c-\rho)^{2}}\right] P_{0} \\
& L_{s}=L_{q}+\rho \\
& W_{q}=\frac{L_{q}}{\lambda} \\
& W_{s}=W_{q}+\frac{1}{\mu}
\end{aligned}
$$

3. Populasi Terbatas dengan Pelayanan Tunggal (M/M/1):(GD/N/ $\infty)$

$$
\begin{aligned}
& \lambda_{n}=\left\{\begin{array}{cc}
\lambda, & n=0,1,2, \ldots, N-1 \\
0, & n=N, N+1
\end{array}\right. \\
& \mu_{n}=\mu \text { untuk semua } \mathrm{n}=0,1,2, \ldots \\
& \rho=\frac{\lambda}{\mu} \\
& P_{n}= \begin{cases}\rho^{n} P_{0} & \text { untuk } n \leq N \\
0 & \text { untuk } n>N\end{cases}
\end{aligned}
$$




$$
\begin{aligned}
& P_{0}= \begin{cases}\frac{1-\rho}{1-\rho^{N+1}}, & \rho \neq 1 \\
\frac{1}{N+1}, & \rho=1\end{cases} \\
& P_{n} \begin{cases}\frac{(1-\rho)}{1-\rho^{N+1}} \rho^{n}, \rho \neq 1 \\
\frac{1}{N+1}, \rho=0,1,2, \ldots N\end{cases} \\
& L_{q}=\left\{\begin{array}{l}
\frac{\rho\left\{1-(N+1) \rho^{N}+k \rho^{N+1}\right\}}{(1-\rho)\left(1-\rho^{N+1}\right)}, \rho \neq 1 \\
\frac{N}{2}, \rho=1
\end{array}\right. \\
& \lambda_{e f f}=\lambda\left(1-P_{N}\right) \\
& L_{s}=L_{q}+\frac{\lambda}{\mu} \\
& W_{q}=\frac{L_{q}}{\lambda_{e f}}=\frac{L_{q}}{\lambda\left(1-P_{N}\right)} \\
& W_{s}=W_{q}+\frac{1}{\mu}=\frac{L_{s}}{\lambda\left(1-P_{N}\right)}
\end{aligned}
$$

4. Populasi Terbatas dengan Pelayanan Majemuk (M/M/c): (GD/N/ $\infty)$

$$
\begin{aligned}
& \lambda_{n}= \begin{cases}\lambda, & 0 \leq n<N \\
0, & n \geq N\end{cases} \\
& \mu_{n}= \begin{cases}n \mu, & 0 \leq n \leq N \\
c \mu, & 0 \leq n \leq N\end{cases} \\
& \rho=\frac{\lambda}{\mu} \\
& P_{n}= \begin{cases}\frac{\rho^{n}}{n !} P_{0}, & 0 \leq n \leq c \\
\frac{\rho^{n}}{c ! c^{n-c}} P_{0}, & c \leq n \leq N\end{cases}
\end{aligned}
$$




$$
\begin{aligned}
& P_{0}= \begin{cases}{\left[\sum_{n=0}^{c-1} \frac{\rho^{n}}{n !}+\frac{\rho^{c}\left(1-\left(\frac{\rho}{c}\right)^{N-c+1}\right.}{c !\left(1-\frac{\rho}{c}\right)}\right]^{-1},} & \frac{\rho}{c} \neq 1 \\
{\left[\sum_{n=0}^{c-1} \frac{\rho^{c}}{n !}+\frac{\rho^{c}}{c !}(N-c+1)\right]^{-1},} & \frac{\rho}{c}=1\end{cases} \\
& L_{q} \\
& =\left\{\begin{array}{cc}
P_{0} \frac{\rho^{c+1}}{(c-1) !(c-\rho)^{2}}\left\{1-\left(\frac{\rho}{c}\right)^{N-c}-(N-c)\left(\frac{\rho}{c}\right)^{N-c}\left(1-\frac{\rho}{c}\right)\right\}, & \frac{\rho}{c} \neq 1 \\
P_{0} \frac{\rho^{c}(N-c)(N-c+1)}{2 c !}, & \frac{\rho}{c}=1
\end{array}\right. \\
& L_{s}=L_{q}+\frac{\lambda_{e f f}}{\mu} \\
& \lambda_{e f f}=\lambda\left(1-P_{N}\right) \\
& W_{q}=\frac{L_{q}}{\lambda_{e f f}} \\
& W_{s}=W_{q}+\frac{1}{\mu}
\end{aligned}
$$

Adapun notasi yang digunakan dalam perhitungan sistem antrian sebagai berikut:

$\lambda \quad=$ Laju kedatangan.

$\mu \quad=$ Laju pelayanan.

$L_{S} \quad=$ Jumlah pelanggan rata-rata yang diharapkan dalam sistem.

$L_{q} \quad=$ Jumlah pelanggan yang menunggu dalam antrian.

$W_{s} \quad=$ Waktu rata-rata yang dihabiskan seorang pelanggan dalam sistem.

$W_{q} \quad=$ Waktu rata-rata yang dihabiskan seorang pelanggan dalam antrian.

$W(t)=$ Peluang bahwa seorang pelanggan menghabiskan waktu lebih dari $\mathrm{t}$ unit waktu di dalam sistem.

$W_{q}(t)=$ Peluang bahwa seorang pelanggan menghabiskan waktu lebih dari $\mathrm{t}$ unit waktu di dalam antrian.

$P_{n} \quad=$ Peluang bahwa di dalam sistem terdapat $\mathrm{n}$ pelanggan .

$P_{0} \quad=$ Peluang bahwa tidak terdapat pelanggan di dalam sistem.

Penelitian mengenai sistem antrian dengan server majemuk telah dilakukan Purnawan (2013) yang menghitung efektifitas sistem antrian M/G/c pada fasilitas pelayanan perbaikan kendaraan bermotor. Farkhan (2013) mengamati efektifitas pelayanan pada antrian di teller bank. Keduanya menggunakan 
simulasi software visual basic untuk perhitungan efektifitas sistem antrian. Seiring dengan pesatnya perkembangan ilmu komputer, saat ini banyak software yang dapat diaplikasikan untuk simulasi dan membantu mempermudah perhitungan. Selain visual basic, salah satu perangkat lunak yang dapat digunakan untuk pemrograman dalam hal ini untuk menghitung sebuah sistem antrian adalah matlab. Matlab merupakan bahasa pemrograman tingkat tinggi yang dikembangkan oleh MathWorks dan dikhususkan untuk komputasi numerik, visualisasi dan pemrograman [4]. Matlab merupakan perangkat lunak yang cocok dipakai sebagai alat komputasi yang melibatkan penggunaan matriks dan vektor [5]. Dengan memanfaatkan Matlab, dapat dilakukan analisis data, pengembangan algoritma dan membuat model maupun aplikasi dan dapat pula dibuat tampilan visual dari suatu program sehingga dapat memudahkan pengguna. Bahasa, tools dan fungsi-fungsi built-in lebih mudah digunakan untuk mengeksplorasi berbagai pendekatan dan memperoleh solusi dengan lebih cepat dibandingkan apabila menggunakan spreadsheets atau bahasa pemrograman tradisional, seperti $\mathrm{C} / \mathrm{C}++$ atau Java ${ }^{\mathrm{TM}}$. Selain itu juga dapat diintegrasikan dengan aplikasi dan bahasa pemrograman eksternal seperti C, Java, .NET dan Microsoft Excel.

Pada penelitian ini dirancang program perhitungan sistem antrian dengan matlab, pembuatan aplikasi dimulai dengan mendesain user-interface, kemudian dilakukan penulisan kode program untuk mencari hasil perhitungan terhadap model antrian. Aplikasi program yang dibuat akan memberikan hasil perhitungan model antrian dengan server tunggal dan majemuk. Hasil perhitungan sistem antrian dengan aplikasi program matlab kemudian akan dibandingkan dengan hasil perhitungan secara teoritis.

\section{METODE}

Pengembangan program aplikasi komputer dengan matlab untuk menghitung aplikasi teori antrian dilakukan dalam beberapa tahapan sebagai berikut:

1) Tahap perancangan program

Perancangan program dimulai dengan membuat flowchart yang menggambarkan proses kerja aplikasi matlab yang dibuat untuk perhitungan model antrian.

2) Tahap pembuatan program (koding)

Pembuatan program dilakukan dengan terlebih dahulu mendesain tampilan program pada GUI matlab, kemudian melakukan pengkodingan perhitungan model-model antrian pada $m$-file.

3) Tahap implementasi program 
Program aplikasi yang dibuat selanjutnya diimplementasikan terhadap kasus antrian dengan menggunakan informasi data waktu kedatangan dan pelayanan pelanggan.

4) Tahap uji coba program

Proses uji coba program dilakukan sejalan dengan tahapan implementasi program. Tahap ini bertujuan untuk menguji ketepatan program yang dirancang untuk menghitung beberapa komponen antrian seperti asumsi distribusi waktu antrian, probabilitas serta beberapa waktu efektif dalam antrian.

5) Tahap evaluasi program.

Pada tahap ini dilakukan analisis kesalahan yang terjadi pada program yang telah dibuat, dibandingkan secara teoritis. Apabila terjadi kesalahan atau ketidaksesuaian antara implementasi program dengan teori maka dilakukan langkah perbaikan.

Dalam tahap implementasi dan uji coba program digunakan data sekunder berupa data antrian yang diambil dari skripsi yang berjudul "Aplikasi Teori Antrian untuk Pengambilan Keputusan pada Sistem Antrian Pelanggan di Kantor Pos Pusat Semarang" [3].

\section{HASIL DAN PEMBAHASAN}

Tahapan yang digunakan untuk menganalisis kerja program ini sebagai berikut:

a) Perancangan Program

Perancangan program mencakup flowchart yang menggambarkan proses jalannya aplikasi matlab yang dibuat untuk perhitungan model antrian seperti terlihat pada Gambar 5 . 


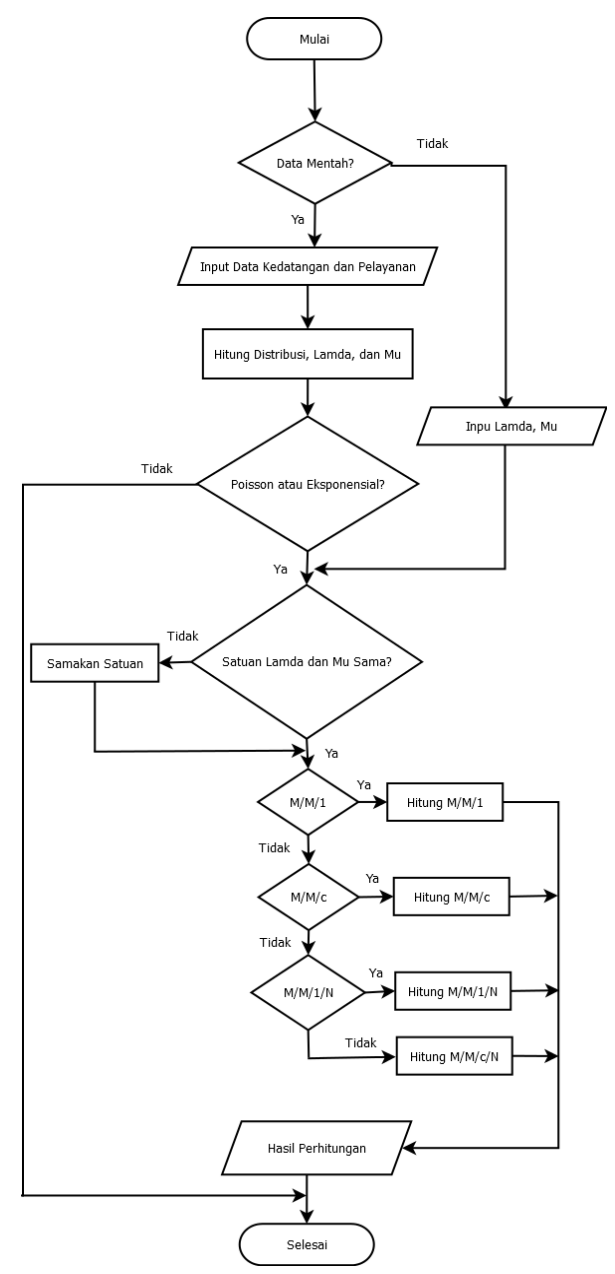

Gambar 5 Flowchart perhitungan model antrian.

b) Pembuatan Program

Setelah dilakukan perancangan, tahap berikutnya adalah tahap pembuatan aplikasi perhitungan model antrian dengan server tunggal dan majemuk menggunakan matlab. Pembuatan program dimulai dari mendesain tampilan program pada GUI yang disediakan matlab, setelah desain selesai kemudian melakukan pengkodingan perhitungan model-model antrian pada $m$-file matlab. Gambar 6 menampilkan desain progam aplikasi sistem antrian yang dirancang. 


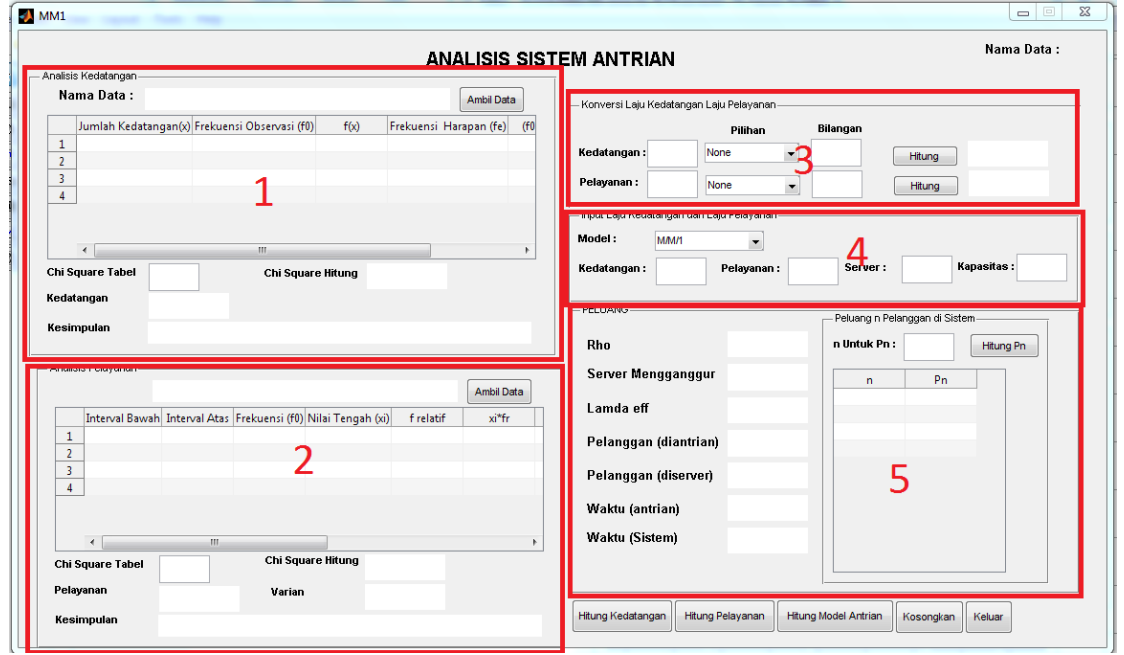

Gambar 6 Desain Tampilan Program.

Desain program yang dibuat terdiri atas beberapa komponen sebagai berikut:

a. Komponen nomor 1 merupakan aplikasi program untuk analisis distribusi laju kedatangan.

b.Komponen nomor 2 merupakan aplikasi program untuk analisis distribusi laju pelayanan.

c. Komponen nomor 3 akan menampilkan konversi hasil laju kedatangan dan pelayanan yang diperoleh dari hasil perhitungan pada komponen 1 dan 2 . Pada bagian ini dapat dilakukan penyesuaian satuan waktu antara laju kedatangan dan pelayanan.

d.Komponen nomor 4 berisi isian data yang diinput yang kemudian akan diproses oleh aplikasi. Pada bagian ini pemakai dapat pula langsung melakukan proses perhitungan model antrian dengan cara menginput data laju kedatangan dan pelayanan dengan syarat memiliki satuan waktu yang sama, jika satuan waktu yang digunakan tidak sama maka proses perhitungan harus dimulai dari komponen sebelumnya (komponen 3) dengan menyamakan satuan waktu terlebih dahulu.

e. Komponen nomor 5 menampilkan hasil perhitungan model antrian yang dipilih.

c) Implementasi Program

Program aplikasi yang sudah dibuat kemudian diimplementasikan terhadap kasus antrian dengan data sekunder yang digunakan.Antrian yang diamati adalah antrian pelanggan Kantor Pos Pusat Semarang, adapun data yang 
digunakan adalah data waktu kedatangan dan pelayanan pelanggan pada hari Selasa, 15 November 2005.Sistem antrian yang diamati mengikuti model antrian dengan server tunggal dan disiplin antrian first in first out.Hasil perhitungan dengan program aplikasi matlab dapat dilihat pada Gambar 7.

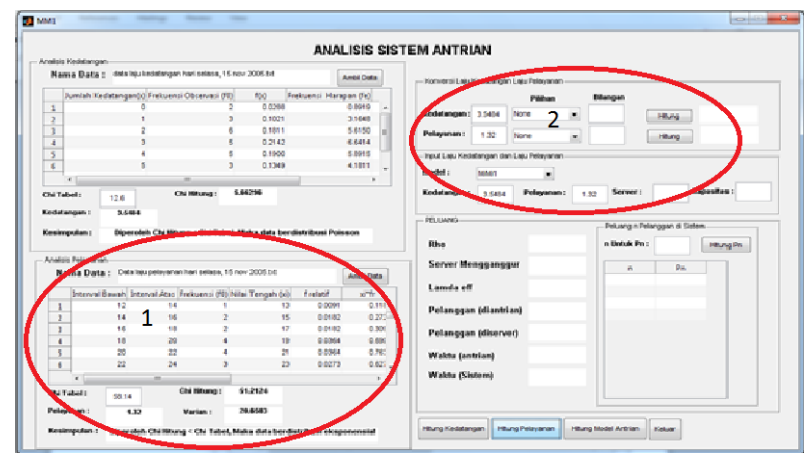

Gambar 7 Hasil Perhitungan Laju Pelayanan.

Gambar 7 menunjukkan hasil perhitungan laju kedatangan, laju pelayanan serta analisis distribusi data laju kedatangan dan pelayanan (bagian 1) dan konversi data (bagian 2). Perhitungan laju pelayanan secara detail dapat dilihat pada Gambar 8.

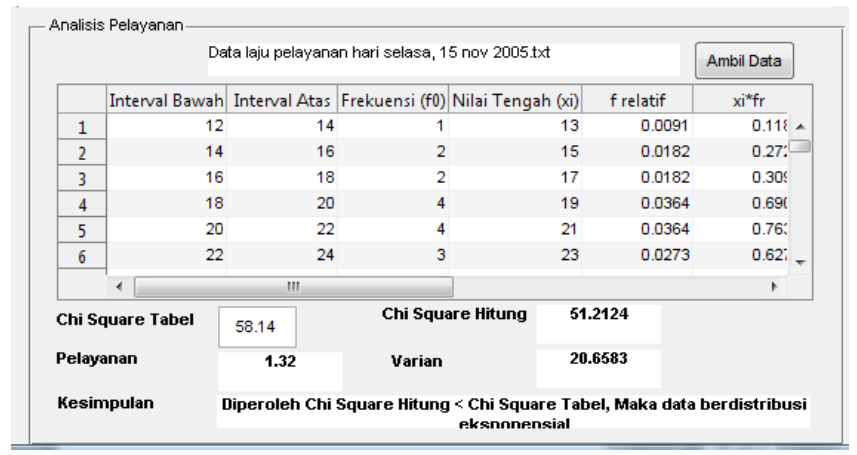

Gambar 8 Hasil Perhitungan Laju Pelayanan. 


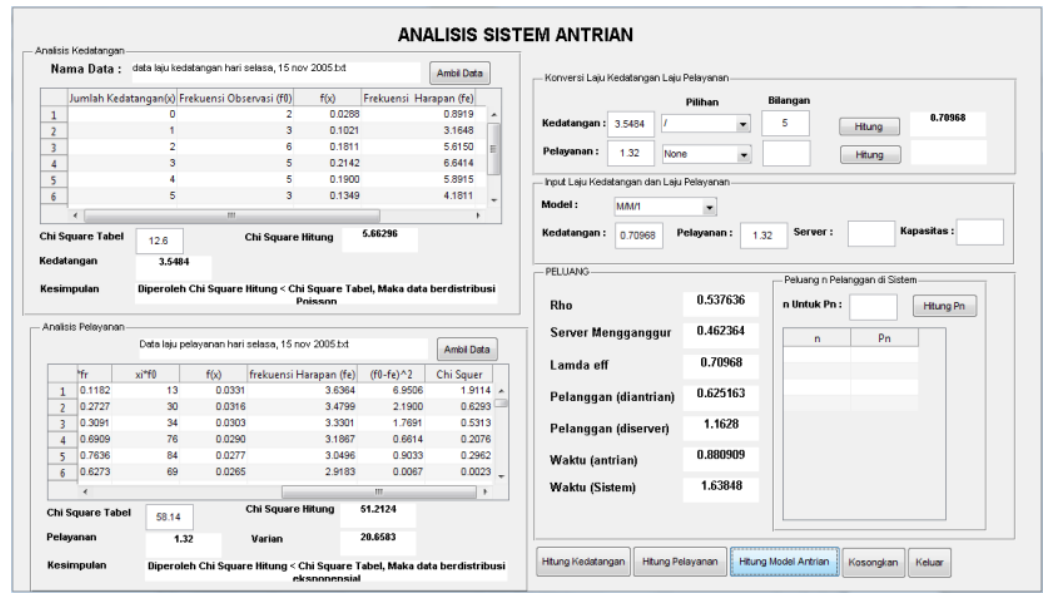

Gambar 9 Hasil Analisis Sistem Antrian.

Gambar 9 menampilkan hasil perhitungan komponen sistem antrian secara lengkap. Terlihat bahwa data antrian memiliki laju kedatangan yang berdistribusi poisson dengan rata-rata 3,5484 pelanggan per lima menit, laju pelayanan berdistribusi eksponensial dengan rata-rata 1,32 pelanggan per menit. Laju pelayanan dengan satuan berbeda ini terlebih dahulu dikonversi untuk dapat memperoleh perhitungan komponen antrian selanjutnya.

\section{d) Uji Coba Program}

Proses uji coba program diperlukan untuk menguji ketepatan program dengan perhitungan secara teoretis. Setelah dilakukan perhitungan menggunakan program aplikasi dan secara teoretis, diperoleh hasil perhitungan yang dirangkumkan dalam Tabel 1 dan Tabel 2.

Tabel 1 Laju kedatangan dan laju pelayanan.

\begin{tabular}{llllcc}
\hline & \multicolumn{3}{c}{ Laju Kedatangan } & \multicolumn{3}{c}{ Laju Pelayanan } \\
\hline & Teoretis & Program & & Teoretis & Program \\
$\lambda$ & 3.5484 & 3.5484 & $\mu$ & 1.32 & 1.32 \\
$\boldsymbol{x}_{\text {tabel }}^{2}$ & 12.6 & 12.6 & $x_{\text {tabel }}^{2}$ & 58.14 & 58.14 \\
$\boldsymbol{x}_{\text {hitung }}^{2}$ & 5.665 & 5.663 & $x_{\text {hitung }}^{2}$ & 51.212 & 51.2124 \\
Kesimpulan & Poisson & Poisson & Kesimpulan & Eksponensial & Eksponensial \\
\hline
\end{tabular}

Dari Tabel 1 terlihat bahwa perhitungan laju dan distribusi waktu kedatangan baik secara teoretis maupun dengan program aplikasi memberikan hasil yang sama. 
Tabel 2 Perhitungan Komponen Sistem Antrian.

\begin{tabular}{lll}
\hline \multicolumn{3}{c}{ Sistem Antrian Kantor Pos Semarang } \\
\hline & Teoretis & Program \\
$\lambda$ & 0.7097 & 0.7097 \\
$\mu$ & 1.32 & 1.32 \\
$\rho$ & 0.538 & 0.5376 \\
$\boldsymbol{P}_{\mathbf{0}}$ & 0.4624 & 0.4624 \\
$\boldsymbol{\lambda}_{\text {eff }}$ & 0.7097 & 0.7097 \\
$\mathbf{L q}$ & 0.6249 & 0.6252 \\
$\mathbf{L s}$ & 1.1625 & 1.1628 \\
$\mathbf{W q}$ & 0.8807 & 0.8809 \\
$\mathbf{W s}$ & 1.6383 & 1.6384 \\
\hline
\end{tabular}

Berdasarkan Tabel 2 hasil antara perhitungan secara teoretis dan program aplikasi secara umum memberikan hasil yang sama. Adanya sedikit perbedaan hasil perhitungan terjadi dikarenakan adanya pembulatan angka di belakang koma. Hasil dari kedua perhitungan tersebut menunjukkan bahwa baik secara teoretis maupun dengan memanfaatkan program aplikasi matlab untuk menghitung sistem antrian memberikan hasil yang cenderung sama. Sehingga program aplikasi yang dikembangkan memiliki tingkat keakuratan yang baik.

e) Evaluasi Program

Pada tahap ini dilakukan analisis kesalahan yang terjadi pada program yang telah dibuat, kemudian dilakukan langkah perbaikan jika terjadi ketidaksesuaian antara aplikasi program dengan hasil perhitungan secara teoretis. Dalam hal ini, karena perhitungan program aplikasi menunjukkan ketepatan hasil yang sama dengan perhitungan teoritis, maka program telah dapat diaplikasikan untuk menghitung sistem antrian.

\section{SIMPULAN}

Berdasarkan hasil penelitian dan pembahasan dapat disimpulkan bahwa program aplikasi matlab untuk menghitung sistem antrian memiliki ketepatan hasil yang sama dengan perhitungan secara teoretis. Sehingga program aplikasi ini layak dipertimbangkan untuk dimanfaatkan dalam membantu proses perhitungan sistem antrian khususnya untuk antrian laju kedatangan yang berdistribusi poisson dan laju pelayanan berdistribusi eksponensial. Selain hasil perhitungan yang akurat, pemanfaatan program aplikasi ini dapat mengefisienkan waktu dalam melakukan perhitungan sistem antrian. 
Program aplikasi matlab yang dirancang terbatas hanya perhitungan antrian pada system antrian dengan server tunggal dan majemuk yang memenuhi asumsi laju kedatangan berdistribusi poisson dan laju pelayanan berdistribusi eksponensial, maka disarankan perlu pengembangan lebih lanjut terhadap program sehingga dapat dirancang program perhitungan sistem antrian dengan laju kedatangan dan pelayanan selain poisson dan eksponensial.

\section{REFERENSI}

[1] Dimyati, Tjutju T. Ahmad., Operations Research, Bandung: Sinar Baru Algensindo Bandung, 2004.

[2] Farkhan, Feri., Aplikasi Teori Antrian dan Simulasi pada Pelayanan Teller Bank, Unnes Journal of Mathematics Vol 2 No 1 ISSN 2252-6943 Hal: 17 -23 , Semarang: Universitas Negeri Semarang.

[3] Kakiay, Thomas J., Dasar Teori Antrian Untuk Kehidupan Nyata, Yogyakarta: Andi, 2004.

[4] Purnawan, Dedy., Analisis Model Antrian Perbaikan Sepeda Motor dengan Menggunakan Program Visual Basic, Unnes Journal of Mathematics Vol 2 No 1 ISSN 2252-6943 Hal: 40 - 45, Semarang: Universitas Negeri Semarang.

[5] Subagyo, Pangestu dkk., Dasar-dasar Operation Research, Edisi 2, Yogyakarta: BPTE, 2000.

[6] Kurniati, Asih.,Aplikasi Teori Antrian untuk Pengambilan Keputusan pada Sistem Antrian Pelanggan di Kantor Pos Pusat Semarang, Skripsi,Unnes, 2006.

[7] Siang, Jong J., Jaringan Syaraf Tiruan \& Pemrogramannya, Yogyakarta: Andi Offset, 2009.

[8] Rani, Septia.,Modul Pelatihan Pemrograman MATLAB, Yogyakarta: Himpasikom UGM. 